\title{
ВЛИЯНИЕ НАРУШЕНИЙ ОБМЕНА ЖЕЛЕЗА ОРГАНИЗМА НА ТЕЧЕНИЕ ЭКСПЕРИМЕНТАЛЬНОЙ ОППОРТУНИСТИЧЕСКОЙ ИНФЕКЦИИ
}

\author{
(С) Леонов В.В. ${ }^{1}$, Миронов А.Ю. ${ }^{2}$, Леонова Л.В. ${ }^{1}$, Пачганов С.А. ${ }^{1}$, Булатов И.А. ${ }^{l}$, Сазонова Н.А. ${ }^{l}$ \\ ${ }^{1}$ Кафедра микробиологии и кафедра гистологии, цитологии и эмбриологии Ханты-Мансийской \\ государственной медицинской академии, Ханты-Мансийск; ${ }^{2}$ Московский научно-исследовательский \\ институт эпидемиологии и микробиологии им. Г.Н. Габричевского, Москва \\ E-mail: andy.60@mail.ru
}

\begin{abstract}
Приведены результаты исследования влияния нарушений обмена железа на транслокацию и выживание $P$. aeruginosa и S. aureus. Моделирование железодефицитной анемии (ЖДА) и гемосидероза (ГС) осуществлялось на лабораторных мышах введением десферриоксамина и сульфата железа(III) соответственно. Заражение осуществляли внутрибрюшинно (доза 1/2LD 50 на мышь), и животных выводили из эксперимента на 12 ч - 48 ч - 72 ч - 15-е сутки после заражения. Определялись микробная обсемененность КОЕ/г внутренних органов (печень, селезенка) и экспрессия генов гемолитической фосфолипазы C $(p l c H)$, альгината $(\operatorname{alg} D)$, экзотоксина А (exoA) для $P$. aeruginosa и генов протеина А $(\operatorname{spaA})$, глобального регулятора вирулентности $(\arg A B C D)$ для $S$. aureus. При ГС наблюдается развитие сепсиса и его фатальное течение. ЖДА снижает экспрессию всех факторов вирулентности P. aeruginosa, однако способствует персистенции возбудителя. Напротив, для $S$. aureus при ЖДА наблюдается развитие сепсиса и увеличение экспрессии основных генов патогенности. Различные эффекты нарушений обмена железа на протекание оппортунистической инфекции обсуждаются с позиции системы «чувство кворума».

Ключевые слова: обмен железа, железодефицитная анемия, гемосидероз, экспрессия генов вирулентности, сепсис, Staphylococcus aureus, Pseudomonas aeruginosa.
\end{abstract}

\section{INFLUENCE OF IRON METABOLISM DISTURBANCES ON THE COURSE OF EXPERIMENTAL OPPORTUNISTIC INFECTION} Leonov V.V. ${ }^{l}$, Mironov A.Yu. ${ }^{2}$, Leonova L.V. ${ }^{l}$, Pachganov S.A. ${ }^{l}$, Bulatov I.A. ${ }^{l}$, Sazonova N.A. ${ }^{l}$

${ }^{1}$ Department of Microbiology; Department of Histology, Cytology and Embryology of Khanty-Mansiysk State Medical Academy, Khanty-Mansiysk;

${ }^{2}$ G.N. Gabrichevsky Moscow Scientific Research Institute of Epidemiology and Microbiology, Moscow

The investigation results of the influence of iron metabolism disturbances on the translocation and survival of $P$. aerugino$s a$ and $S$. aureus have been presented. Modeling iron deficiency anemia (IDA) and hemosiderosis (HS) was carried out on laboratory mice by introducing desferrioxamine and iron sulphate (III), respectively. Infection was carried out intraperitoneally (dose $1 / 2 \mathrm{LD}_{50}$ per mouse) and animals were withdrawn from the experiment $12 \mathrm{~h}-48 \mathrm{~h}-72 \mathrm{~h}-15$ days after being infected. We determined the degree of microbial contamination CFU/g of the internal organs (liver, spleen), the genes expression of hemolytic phospholipase $\mathrm{C}(\mathrm{plcH})$, alginate $(\operatorname{alg} D)$, exotoxin A (exoA) for $P$. aeruginosa and protein A gene (spaA), a global regulator of virulence $(\arg A B C D)$ for $S$. aureus. The development of sepsis and lethal outcomes may be observed in HS. IDA reduces the expression of virulence factors of $P$. aeruginosa, but contributes to the persistence of the parasite. By contrast, the sepsis development and the increase in the expression of general genes of pathogenicity occur for $S$. aureus in IDA. Different effects of iron metabolism disturbances on the course of experimental opportunistic infection are being discussed from the position of «quorum sensing» system in bacteria.

Keywords: iron metabolism, iron deficiency anemia, hemosiderosis, expression of virulence genes, sepsis, Staphylococcus aureus, Pseudomonas aeruginosa.

Несмотря на изученность биологической роли железа, его гомеостаза в организме человека, до сих пор одним из самых распространенных дисмикроэлементозов в мире является гипо- и гемосидероз. Особое значение данная проблема имеет для жителей северных территорий России, где распространены гипосидерозы различного генеза и алиментарные гемосидерозы, связанные с высоким содержанием железа и марганца в подземных водах. Железо является универсальным регулятором экспрессии факторов патогенности микроорганизмов, влияет на инфекционную чувствительность организма хозяина. Работы по исследованию влияния обмена железа на инфек- ционную чувствительность и протекание инфекционного процесса противоречивы.

Актуально изучение вопросов взаимодействия возбудителей инфекций с организмом хозяина в зависимости от нагрузки организма железом. Изучение этой проблемы наиболее значимо для внеклеточных условно-патогенных микроорганизмов - возбудителей оппортунистических инфекций, рост и размножение которых существенным образом зависят от условий окружающей среды [6; 7].

Цель работы - выяснить влияние нарушений обмена железа организма лабораторных животных на особенности протекания эксперименталь- 
ной оппортунистической стафилококковой и синегнойной инфекций.

\section{МАТЕРИАЛЫ И МЕТОДЫ ИССЛЕДОВАНИЯ}

В качестве экспериментальных животных использованы белые лабораторные мыши CD-1 5-6-недельного возраста массой 22-25 г из питомника Института цитологии и генетики СО РАН. Число мышей в каждой группе составляло 25 особей.

Животные разделены на 3 группы: I - интактные (группа сравнения - N); II - группа с дефицитом железа (ЖДА); III - группа с гемосидерозом (ГС). Моделирование ЖДА осуществлялось трехкратным подкожным введением 0,5 г/кг с интервалом через 3 дня хелатора железа - десферриоксамина (Desferal ${ }^{\circledR}$, Novartis, Германия) [8]. Моделирование ГС проводили путем трехкратного внутрибрюшинного введения 0,5 г/кг с интервалом в 3 дня сульфата железа(III) (ФеррумЛек ${ }^{\circledR}$, Россия) [10]. Интактной группе вводили физиологический раствор подкожно и внутрибрюшинно. Животные I и III групп содержались на смешанном сбалансированном рационе с оптимальным соотношением белков, липидов, углеводов, минеральных компонентов. Животные II группы содержались в пластиковых клетках и находились на смешанном рационе с оптимальным соотношением белков, липидов, углеводов, не исключающем железо. Для контроля параметров гомеостаза железа при моделировании ЖДА и ГС использовали фотоэлектроколориметрический метод определения гемоглобина, ферритина и сывороточного железа.

В качестве оппортунистических патогенов использовали штаммы Pseudomonas aeruginosa 9399 и Staphylococcus aureus 545, выделенные из крови больных ОКБ г. Ханты-Мансийска. Заражение животных осуществлялось внутрибрюшинным введением суспензии штаммов оппортунистических микроорганизмов в дозе, соответствующей половине минимальной летальной дозы $\left(\mathrm{LD}_{50}\right)$, что позволяло изучить транслокацию возбудителя из брюшной полости во внутренние органы и его выживание в зависимости от железонагруженности организма. Животные всех групп выводили из эксперимента на 12 ч - 48 ч - 72 ч 15 -е сутки после заражения. Для характеристики течения инфекционного процесса использовался контроль микробной обсемененности внутренних органов и их массы, изучалась экспрессия основных факторов патогенности в печени.

Для оценки микробной обсемененности сердца, печени, селезенки стандартные навески этих органов гомогенизировали на холоду в стерильном физиологическом растворе, полученный го- могенат разводили (цельный, 1:5, 1:10 и 1:20) и по 0,2 мл высевали на поверхность 5\% кровяного агара. Штаммовую идентификацию выделенного из органов микроорганизма определяли по профилю чувствительности к антибиотикам.

Для изучения экспрессии факторов патогенности $S$. aureus и $P$. aeruginosa выбраны наиболее важные для выживания в крови - факторы, способствующие биопленкообразованию, токсины, гемолитическая фосфолипаза С. Для P. aeruginosa - ген гемолитической фосфолипазы $\mathrm{C}-p l c H$, АДФ-рибозилазного экзотоксина $\mathrm{A}_{2}-$ exoA, синтеза альгината $\operatorname{alg} D$; для $S$. aureus транскрипт РНК III локуса $\arg A B C D$, обеспечивающего регуляцию синтеза основных факторов патогенности (ДНК-азы, фибринолизина, энтеротоксина, $\alpha$-, $\beta$-, $\delta$-токсинов и др.), ген протеина А $\operatorname{spaA}$ (фактор адгезии). В качестве гена «домашнего хозяйства» использован универсальный праймер для гена бактериальной $16 \mathrm{~S}$ рРНК. Структура праймеров и условия ПЦР описаны [2]. Праймеры и наборы для обратной транскрипции произведены ЗАО Евроген (Россия). Для проведения ПЦР использован термоциклер CFX 96 (Bio$\mathrm{Rad}, \mathrm{CШA).} \mathrm{Анализ} \mathrm{данных} \mathrm{проведен} \Delta \mathrm{Ct}$-методом с применением референс-гена, который используется для относительной количественной оценки экспрессии генов [1]. Уровень экспрессии генов выражался в условных единицах.

Эвтаназию животных осуществляли декапитацией под эфирным наркозом. Все эксперименты с лабораторными животными одобрены локальным этическим комитетом БУ «Ханты-Мансийская государственная медицинская академия», рег. номер 106 от 11.05.2016.

Статистическая обработка результатов проводилась с использованием t-критерия Стьюдента и программы Microsoft Office Excel 2003.

\section{РЕЗУЛЬТАТЫ ИССЛЕДОВАНИЯ И ИХ ОБСУЖДЕНИЕ}

Для $P$. aeruginosa 9399 установлено, что заражение животных в дозе соответствующей $\mathrm{LD}_{50}-$ $10^{4} \mathrm{KOE} /$ мышь ведет к транслокации возбудителя из брюшной полости во внутренние органы и развитию сепсиса во всех группах животных. На протяжении всего эксперимента в группе с ГС регистрировали наибольшую гибель животных (10 из 25) 32\% на третьи и четвертые сутки. В группах с нормальным гомеостазом железа и ЖДА гибель животных ниже (2 из 25) - до 8\%. Этим данным соответствуют и результаты определения микробной обсемененности $P$. aeruginosa $(\operatorname{lgKOЕ} / \Gamma)$ внутренних органов у животных исследуемых групп (рис. 1А). На всех сроках наблюдения этот показатель выше при ГС. 


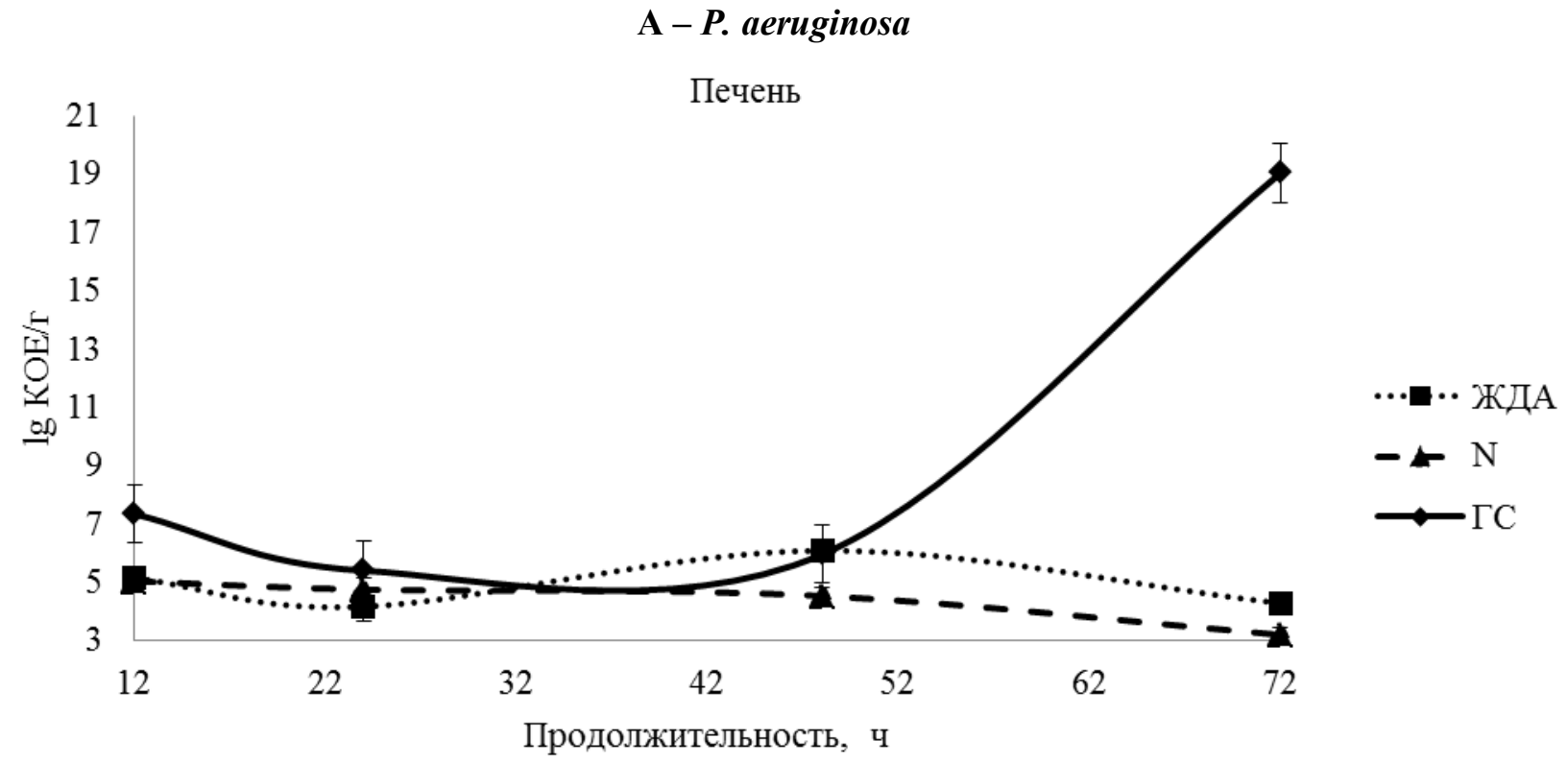

Селезенка

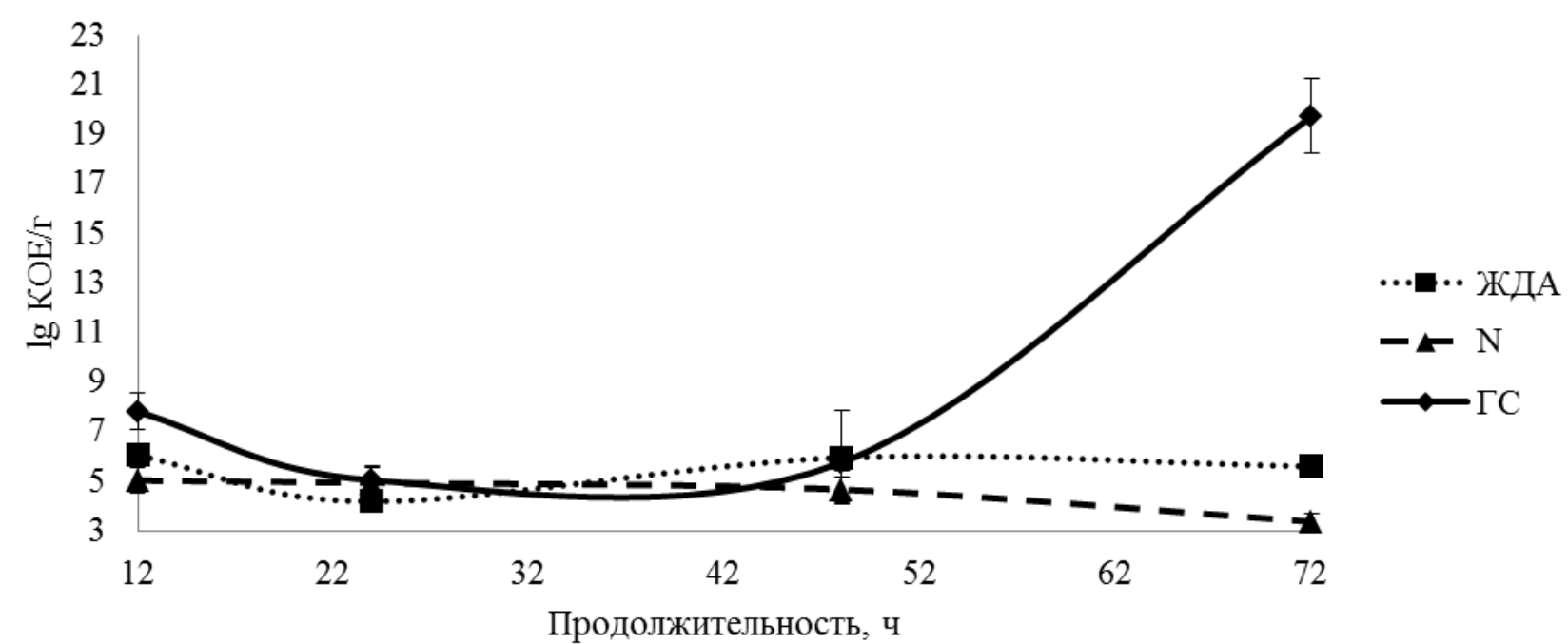

Б - S. aureus

Печень

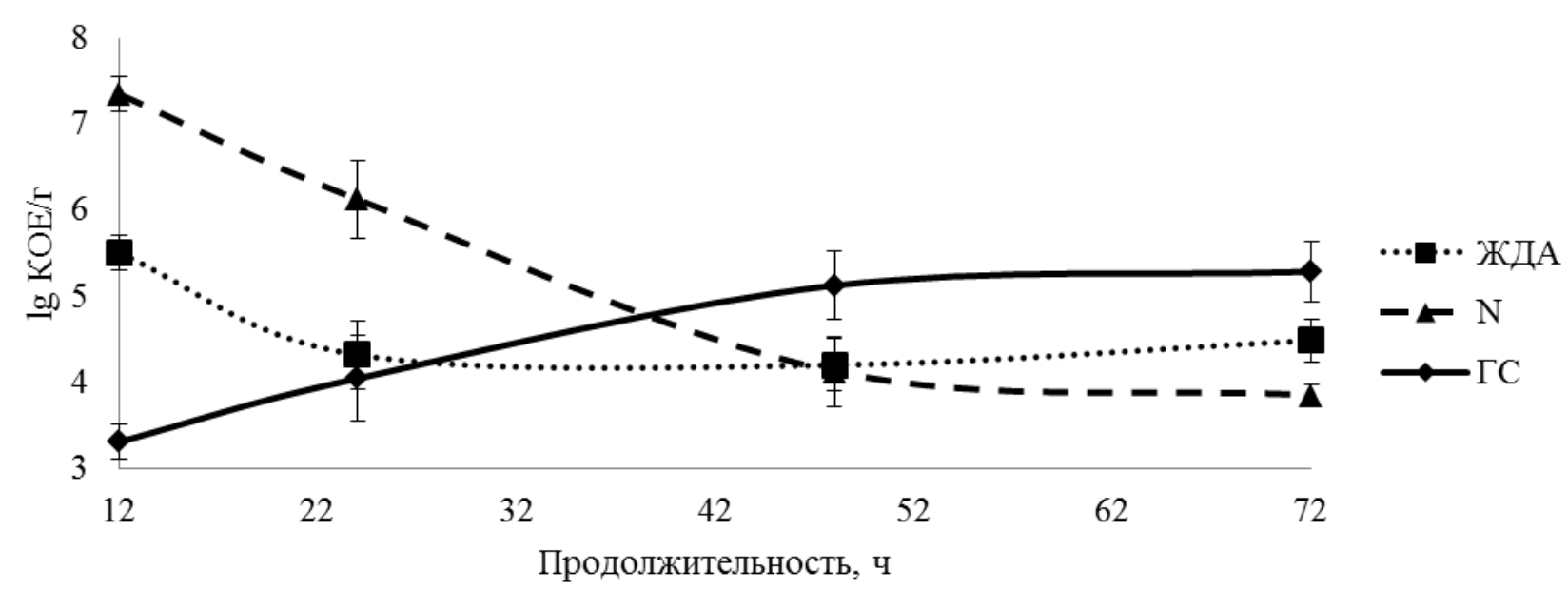

Рис. 1. Влияние нагрузки организма железом на протекание экспериментальной оппортунистической инфекции у мышей CD-1. 
Б (продолжение) - S. aureus

Селезенка

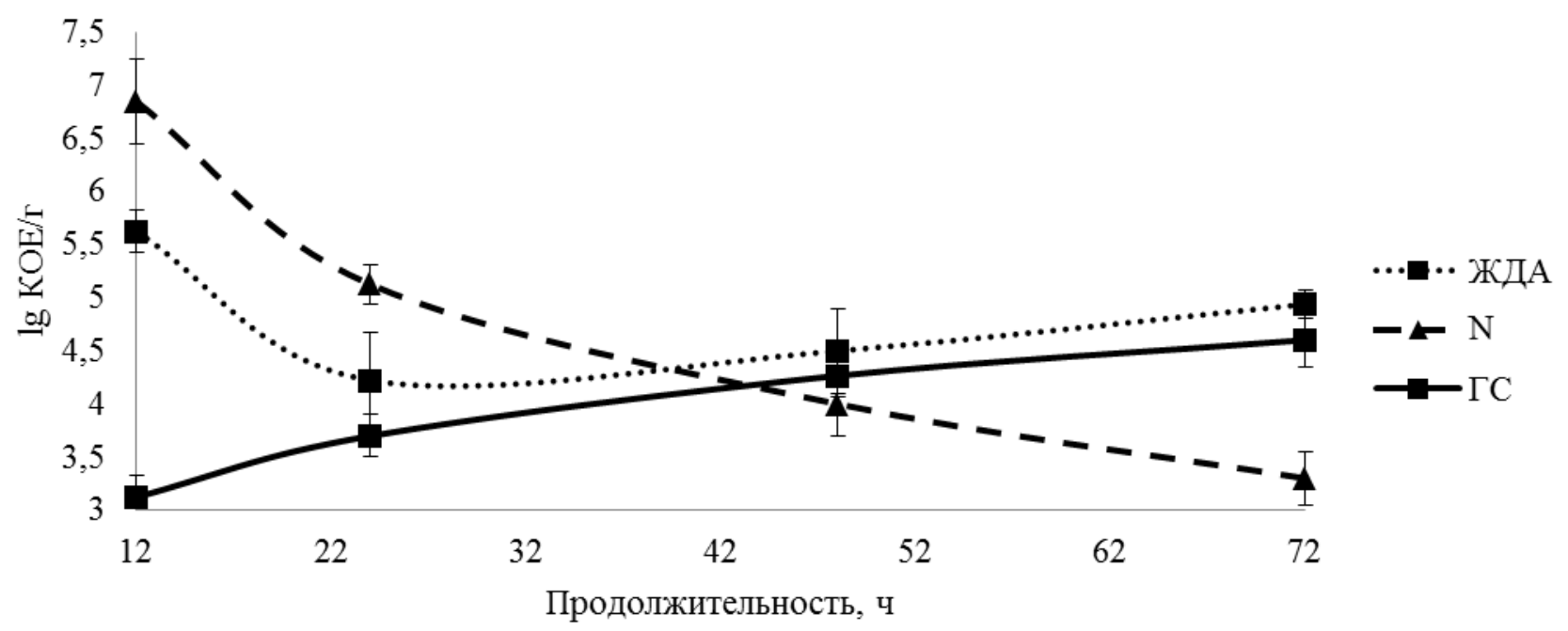

Рис. 1 (продолжение). Влияние нагрузки организма железом на протекание экспериментальной оппортунистической инфекции у мышей $\mathrm{CD}-1$.

Активность роста $P$. aeruginosa при ЖДА незначительно отличалась от нормы. Значение $\mathrm{KOE} / \Gamma \quad P$. aeruginosa в селезенке на 3-е сутки эксперимента достоверно выше при ЖДА, чем в группе с нормальным гомеостазом железа. За выжившими мышами наблюдали еще в течение 12 суток (15-и сутки эксперимента). Гибель мышей наблюдалась только в группе с ГС. При этом из селезенки мышей с ЖДА и нормой высевался возбудитель в концентрации $10^{2} \mathrm{KOЕ} / г$, что может свидетельствовать о персистенции возбудителя.

Для $S$. aureus 545 установлено, что заражение животных в дозе, соответствующей $\mathrm{LD}_{50}$ $10^{6} \mathrm{KOE/мышь,} \mathrm{ведет} \mathrm{к} \mathrm{транслокации} \mathrm{возбудителя}$ из брюшной полости во внутренние органы во всех группах животных. На протяжении всего эксперимента в группе с ГС (3 из 25) и ЖДА (2 из $25)$ регистрировали гибель животных $12 \%$ и $8 \%$ на третьи и четвертые сутки. Как и в предыдущем случае, за выжившими мышами наблюдали в течение 15 суток. Наибольшая гибель мышей наблюдалась в только группах с ГС и ЖДА на 10-й день эксперимента.

Результаты определения микробной обсемененности $S$. aureus $(\operatorname{lgKOЕ} / г)$ внутренних органов у животных исследуемых групп показаны на pис. 1Б. В отличие от $P$. aeruginosa, количество $S$. aureus во внутренних органах через 12 ч после заражения наибольшее в группе мышей с нормальным обменом железа и резко уменьшалось на протяжении всего эксперимента. Наименьшее количество $S$. aureus через 12 ч после заражения наблюдалось в группах мышей с ГС и ЖДА. Через 24 ч количество $S$. aureus во внутренних органах начинало плавно увеличиваться в группах с ЖДА и ГС на протяжении всего срока наблюдения. Наибольшие значения обсемененности $\operatorname{lgKOE} / г$ по сравнению с нормой наблюдались в группе мышей с ГС для печени и в группе мышей с ЖДА для селезенки. В группах с ГС и ЖДА $S$. aureus продолжал выделяться и на 15-е сутки из всех внутренних органов в количестве $10^{3}$ и $10^{2} \mathrm{KOE} / \Gamma$ соответственно, в группе мышей с нормальным обменом железа $S$. aureus полностью элиминировался из организма к этому сроку наблюдения.

Массивность обсеменения $S$. aureus и $P$. aeruginosa внутренних органов мышей сильно зависела от обмена железа организма мышей. При ГС обсемененность всех изученных внутренних органов наибольшая. ЖДА способствует росту $S$. aureus, однако существенно подавляет рост $P$. aeruginosa по сравнению с ГС. Показатели микробной обсемененности всех органов в условиях нормального обмена железа постепенно снижаются в динамике инфекционного процесса.

На втором этапе исследования изучалась экспрессия факторов патогенности in vivo. Для исследования выбрана печень как наиболее обсемененный микроорганизмами орган. Данные об экспрессии основных факторов патогенности $P$. aeruginosa и $S$. aureus приведены в табл. 1.

По мере увеличения количества железа в организме при переходе от состояния ЖДА к ГС увеличивается экспрессия всех изученных генов $P$. aeruginosa. Наиболее железозависим ген $\operatorname{alg} D$, его экспрессия увеличивалась в 2,8 и 4,5 раза в норме и при ГС по сравнению с ЖДА. В отличие от $P$. aeruginosa экспрессия изученных генов патогенности $S$. aureus в зависимости от варианта 
нарушения обмена железа существенно отличалась. РНК III является одним из двух транскриптов локуса $\arg A B C D$, кодирующего синтез ведущих факторов патогенности $S$. aureus. Изучение экспрессии РНК III выявило, что при ЖДА и ГС, по сравнению с нормой, экспрессия генетического локуса $\arg A B C D$ увеличивается. В организме животных I группы происходит подавление роста $S$. aureus, что ингибирует кворум-зависимую регуляцию экспрессии факторов патогенности локуса $\arg A B C D$ [9]. Действительно, микробная обсемененность органов мышей наибольшая в группах мышей с ЖДА и ГС по сравнению с группой с нормальным вариантом обмена железа. Увеличение экспрессии факторов патогенности $S$. aureus в железодефицитных условиях можно связать с активацией способов получения железа. Аналогичные результаты получены для экспрессии гена протеина А spaA. При избытке железа экспрессия гена spaA увеличивалась по отношению к норме в 167,6 раза, в случае дефицита железа лишь в 9 раз. Полученные результаты подтверждают полученные ранее данные по экспрессии и ростовой активности $S$. aureus и $P$. aeruginosa в сыворотке крови в зависимости от содержания сывороточного железа [2].

На примере $S$. aureus и $P$. aeruginosa сделана попытка объяснить роль обмена железа организма хозяина в транслокации и выживании оппортунистических патогенов при экспериментальной инфекции. ГС способствует транслокации и размножению $P$. aeruginosa в организме мышей. $P$. aeruginosa относится к сильно железозависимым микроорганизмам $[5,4]$, логично, что ГС способствует транслокации и ведет к развитию фатального сепсиса. При истинной ЖДА ор- ганизм в принципе не содержит железа, что уменьшает микробную обсемененность и вирулентность $P$. aeruginosa. В условиях нашего эксперимента ЖДА способствовала персистенции P. aeruginosa. В аналогичных условиях в организме мышей с нормальным содержанием железа подавляется размножение $S$. aureus, а ЖДА и ГС увеличивают микробную обсемененность внутренних органов и экспрессию факторов патогенности $S$. aureus. $S$. aureus является менее железозависимым микроорганизмом, по сравнению c P. aeruginosa, однако чаще вызывает генерализованные инфекции $[4,3]$. Полученными результатами можно объяснить широкую распространенность стафилококкового сепсиса в инфекционной патологии человека. Поскольку независимо от состояния обмена железа организма хозяина возможности стафилококка для транслокации и выживания выше, чем у $P$. aeruginosa.

На основании проведенных исследований можно сделать следующие выводы:

- течение экспериментальной синегнойной инфекции существенно зависит от обмена железа. При ГС наблюдается развитие сепсиса и его фатальное течение. ЖДА снижает вирулентность $P$. aeruginosa, однако способствует персистенции возбудителя;

- течение экспериментальной стафилококковой инфекции зависит от обмена железа. При ГС и ЖДА наблюдается развитие сепсиса и увеличение экспрессии основных генов патогенности $S$. aureus. В наибольшей степени вирулентность $S$. aureus проявляется в условиях ГС, ЖДА способствует персистенции возбудителя.

Таблица 1

Экспрессия генов патогенности P. aeruginosa и S. aureus в печени в зависимости от обмена железа организма лабораторных мышей

\begin{tabular}{|c|c|c|c|}
\hline \multirow{3}{*}{ Ген } & \multicolumn{3}{|c|}{ Состояние обмена железа } \\
\hline & ЖДА & Норма & $\Gamma \mathrm{C}$ \\
\hline & \multicolumn{3}{|c|}{ P. aeruginosa } \\
\hline plcH & $8,8 \pm 0,3$ & $15,2 \pm 0,7$ & $18,6 \pm 0,3$ \\
\hline exoA & $68,2 \pm 8,5$ & $92,5 \pm 5,4$ & $134,4 \pm 10,3$ \\
\hline \multirow[t]{3}{*}{$\operatorname{alg} D$} & $498,8 \pm 18,2$ & $1398,8 \pm 16,8$ & $2237,2 \pm 17,5$ \\
\hline & \multicolumn{3}{|c|}{ S. aureus } \\
\hline & ЖДА & Норма & $\Gamma \mathrm{C}$ \\
\hline PHK III & $20,8 \pm 0,4$ & $8,3 \pm 0,5$ & $82,9 \pm 1,5$ \\
\hline $\operatorname{spaA}$ & $6,3 \pm 0,5$ & $0,7 \pm 0,3$ & $117,3 \pm 0,2$ \\
\hline
\end{tabular}




\section{ЛИТЕРАТУРА}

1. Ермилова Е.В., Залуикая Ж.М., Лапина Т.В., Матвеева T.B. Количественный анализ экспрессии генов. Учебное пособие. - СПб. : ТЕССА, 2010. $104 \mathrm{c}$.

2. Леонов В.В., Булатов И.А., Миронов А.Ю. Рост и экспрессия факторов вирулентности условнопатогенных микроорганизмов в сыворотке крови при разных вариантах гомеостаза железа // Клиническая лабораторная диагностика. - 2016. Т. 61, № 8. - С. 498-501.

3. Леонов В.В., Миронов А.Ю., Леонова Л.В., Никитина Л.Ю. Этиологическая структура и биологические свойства возбудителей инфекций кровотока // Клиническая лабораторная диагностика. - 2016. T. 61, № 11. - С. 790-793.

4. Леонов В.В., Миронов А.Ю. Железо и микроорганизмы. - Ханты-Мансийск: ООО «Печатный мир г. Ханты-Мансийск», 2016. - 190 с.

5. Леонов В.В., Молчанова Т.Н. Влияние железа на ростовые характеристики условно-патогенных бактерий // Медицинская наука и образование Урала. - 2011. - Т. 12, № 4. - С. 41-43.
6. Миронов А.Ю., Леонов В.В. Железо, вирулентность и межмикробные взаимодействия условно-патогенных микробов // Успехи современной биологии. - 2016. - Т. 136, № 3. - С. 285-294.

7. Миронов А.Ю., Харсеева Г.Г., Клюкина Т.В. Основы клинической микробиологии. - Ростов-наДону: ГОУ ВПО РостГМУ, 2011. - 248 с.

8. Способ моделирования железодефицитной анемии: заявка RU2014129570A Россия / Дыгай A.M., Удут Е.В., Бурмина Я.В., Сотникова Л.С., Мирошниченко Л.А., Симанина Е.В., Зюзьков Г.Н., Жданов В.В., Удут В.В., Минакова М.Ю. № 216.013.553F; заявлено $17.07 .2014 ;$ опубл. 10.06.2015, 4 c.

9. Oogai Y., Matsuo M., Hashimoto M., Kato F., Sugai M., Komatsuzawa H. Expression of virulence factors by Staphylococcus aureus grown in serum // Appl Environ Microbiol. - 2011. - Vol. 77, N 22. P. 8097-105. - doi: 10.1128/AEM.05316-11.

10. Sawatzki G, Hoffmann F. A., Kubanek B. Acute Iron Overload in Mice: Pathogenesis of Salmonella typhimurium Infection // Infection and Immunity. 1983. - Vol. 39, N 2. - P. 659-665. 